\title{
Local Government Capacity in Australia
}

\author{
Roberta Ryan, Ronald Woods
}

\author{
University of Technology, Sydney
}

cross $^{\text {ref }}$ http://dx.doi.org/10.5755/j01.ppaa.14.3.13433

\begin{abstract}
This paper analyses how effectively local government in Australia performs its functions as a key element of subnational governance. Service delivery and local democracy are identified as the core functions of local government. The analysis takes into account paradigms of public administration, democracy and management, the public organization, accountability and capacity. The concept of 'capacity' brings together many of the issues discussed in this paper. Questions of capacity relate to whether local governments are effectively performing their institutional functions, how they do so with regard to principles of good governance, and whether the dimensions of their capacity can be reformed if there was the need to meet additional demands.
\end{abstract}

Keywords: Local Government in Australia; subnational governance; functions of local government; institutional capacity of local government, local government governance.

Raktažodžiai: Australijos vietos valdžia; subnacionalinis valdymas; vietos valdžios funkcijos; instituciniai vietos valdžios gebejjimai; vietos valdžios valdymas.

\section{Introduction}

Australia, the world's sixth-largest country by land area $\left(7,692,024 \mathrm{~km}^{2}\right)$, is home to one of the oldest living cultures, that of the Aboriginal Australians, and is today a complex, multicultural nation. In a country that is semi-arid and arid in substantial parts, the population of nearly 24 million is unevenly distributed and highly urbanized, with $71 \%$ of the population residing in a Major City. The population is growing by around $1.8 \%$ per annum, and population growth tends to be most prominent in the outer suburbs of metropolitan areas, inner cities, urban infill areas and along the coast [3].

Economically - and increasingly socially - identified as a nation within the burgeoning Asia-Pacific region, Australia's colonial past has bequeathed to the country a constitutional monarchy solidly located in liberal democratic traditions common to the developed countries of the Anglosphere. Australia was one of the first 
countries to establish democracy in the modern world, including being among the first to give women the vote. The mixed economy relies heavily on the services and construction sectors for employment and on the primary resources sector (especially mining) for its economic health, contributing to uneven growth and prosperity in the various regions of the country.

All of these factors have an influence on the structure and functioning of Australian local government. The aim of this paper is to explore whether local government in Australia performs its legislated functions in an effective and efficient way, and how local councils do so with regard to principles of good governance, especially transparency, accountability, the rule of law, local democracy and the involvement of communities and non-government community organizations.

\section{Conditions under which Local Government Functions in Australia}

In this section, we consider the contextual, structural, institutional and human resource conditions that have an impact on the capacity of Australian local government to carry out its functions.

\section{Contextual conditions}

After tens of thousands of years of settlement by Aboriginal Australians, parts of the Australian mainland and neighboring islands were mapped by Dutch, French and British navigators in the $17^{\text {th }}$ and $18^{\text {th }}$ centuries. From 1788, Britain established penal colonies in New South Wales, Tasmania and Western Australia. Free settlers followed in increasing numbers, and relatively soon outnumbered convicts and corrective personnel.

The origins and development of local government in Australia is characterized by a series of tensions. From the early 1800s, the British Colonial Office made it clear to the colonies that it would not provide funding for local services such as roads, as it believed these were matters for local landowners [24]. This need for groups of landowners to fund the development of local services established the spatial or territorial basis for local government as an organizing principle [6]. At the same time, it resulted in local government adopting a narrower range of services compared to its European counterparts, and often being regarded as little more than an administrative arm of their respective colonial state governments. Starting in Adelaide, South Australia in 1840, local governments were gradually established in localities throughout the country to enable these governments to deliver local services and allow local residents to contribute to their cost.

The Commonwealth of Australia was created in 1901 when the British colonies that had become established on the territory of the Australian mainland and Tasmania agreed to federate. These now form the six states of Australia (New South Wales; Victoria; Queensland; Tasmania; South Australia; and Western Australia), each with its own capital city, popularly elected legislature and administration. There are ten Australian territories outside the borders of the states and, of these, the Australian Capital Territory (ACT), the Northern Territory and Norfolk Island are granted a 
limited right of self-government by the Australian Government [4]. Australia is thus an example of a 'coming together' federation in the sense that it was formed through aggregation of previously existing governments [18, p. 222].

\section{Socio-economic Situation of Country}

Australia is the fourth largest economy in the Asian region and the $12^{\text {th }}$ largest economy in the world. The country was ranked second in the United Nations Development Programme's Human Development Report 2014. According to the Organization for Economic Cooperation and Development (OECD), Australia performs favorably with respect to many measures of well-being. Key data for Australia, compared with the average of the 30 developed countries in the OECD, are provided in Table 1.

Table 1. Australia: Key socio-economic data and comparisons with other OECD countries

\begin{tabular}{|c|c|c|}
\hline Indicator & Australia & $\begin{array}{l}\text { OECD average ( } 30 \\
\text { countries) }\end{array}$ \\
\hline Life expectancy at birth & $\begin{array}{l}\text { Women }-84 \text { years } \\
\text { Men }-80 \text { years }\end{array}$ & $\begin{array}{l}\text { Women }-83 \text { years } \\
\text { Men }-77 \text { years }\end{array}$ \\
\hline $\begin{array}{l}\text { Average household net-adjusted per } \\
\text { capita disposable income }\end{array}$ & US\$ 31,197 per year & US $\$ 23,938$ per year \\
\hline $\begin{array}{l}\text { Average expenditure on housing } \\
\text { (proportion of gross disposable income) }\end{array}$ & $20 \%$ & $21 \%$ \\
\hline $\begin{array}{l}\text { High school qualification (proportion } \\
\text { of adults aged 25-64) }\end{array}$ & $74 \%$ & $75 \%$ \\
\hline Working-age population in a paid job & $72 \%$ & $65 \%$ \\
\hline $\begin{array}{l}\text { Gender difference in employment } \\
\text { (percentage points) }\end{array}$ & 13 & 16 \\
\hline Unemployed for a year or longer & $1.1 \%$ & $2.7 \%$ \\
\hline Youth unemployment rate & $11.7 \%$ & $16.3 \%$ \\
\hline $\begin{array}{l}\text { Voter turnout in most recent national } \\
\text { elections }\end{array}$ & $93 \%^{1}$ & $72 \%$ \\
\hline $\begin{array}{l}\text { Engagement in volunteering activities } \\
\text { (average minutes per day) }\end{array}$ & 6 & 4 \\
\hline $\begin{array}{l}\text { Rating of general satisfaction with life } \\
\text { (scale from } 0-10 \text { ) }\end{array}$ & 7.4 & 6.6 \\
\hline
\end{tabular}

Source: adapted from OECD (2014)

\footnotetext{
${ }^{1}$ Voting is compulsory in Australia
} 
These data suggest that Australia compares favorably with other developed nations on a range of socio-economic criteria. At the same time, Australia ranks $21^{\text {st }}$ out of 30 countries in terms of social inequality, with the top $20 \%$ of the population earning almost six times as much as the bottom $20 \%$. Women are still less likely than men to participate in the labor market in Australia [30].

Australia is a highly diverse country. According to the 2011 Census, around 3\% of the Australian population (approximately 670000 people) were estimated as being of Aboriginal or Torres Strait Islander origin (i.e. Indigenous Australians) [34]. Around one quarter $(24.6 \%)$ of the population was born in a country other than Australia, $43.1 \%$ of people have at least one overseas-born parent and $8.5 \%$ of people were born in non-English speaking countries [3].

Australia's Aboriginal and Torres Strait Islander peoples are disadvantaged across many areas of social concern, including life expectancy, child mortality, school attendance and achievement, and employment [34]. A profound socio-economic challenge for the country has been to effectively address Indigenous disadvantage and reduce the 'gap' between Indigenous and non-Indigenous people in terms of these key indicators, while also acknowledging changes over time in outcomes for Indigenous Australians, not linked to the gap to non-Indigenous Australians. Data from 2014 [34] suggest that there have been improvements in life expectancy, young child mortality and high school completion, but that challenges remain with regards to mental health, suicide and self-harm and imprisonments and juvenile detention.

While there have also been challenges relating to the settlement and integration of people, including refugees, from a wide range of countries, Australia's official policy of multiculturalism 'aims to strengthen social cohesion through promoting belonging, respecting diversity and fostering engagement with Australian values, identity and citizenship, within the framework of Australian law' [14].

Australia is fully integrated into the global world economy and is thus strongly impacted upon by macroeconomic trends, particularly as regards trade, currency values and the demand for commodities. A key economic feature of the past few decades has been Australia's enhanced role as supplier of key minerals such as iron ore and coal to major economies such as China, Japan, South Korea and India, which has led to a mining boom. This has had noteworthy impacts on investment and economic development in diverse parts of the country, as well as enabling the country to avoid the worst consequences of the Global Financial Crisis which affected most major economies from 2008. Data provided in Table 1 suggest that the employment rate, including youth employment rate, remains favorable in comparison to other countries of the OECD.

\section{The Constitution and Legislation}

The federal government, which can also be referred to as the Commonwealth of Australia or the Australian Government, follows the British (Westminster) tradition in being a constitutional monarchy, with a Governor-General representing the Crown (Queen Elizabeth II) and Prime Minister as the head of the country. The Federal 
Parliament passes laws which affect the country as a whole. Like the United States of America, and unlike Britain, Australia has a written Constitution which defines the responsibilities of the Federal Government, which include foreign relations, trade, defense and immigration. Governments of the States and Territories are responsible for all matters not assigned to the Commonwealth. This includes public health services and primary and secondary school education. A federal law overrides any state law that is not consistent with it.

A distinctive feature of the Australian federal model is that there is a relatively high degree of shared functions between governments [29, p. 21] so that, in practice, the Commonwealth and States/Territories cooperate in many of the areas that are the formal responsibility of second-tier government, such as education, employment, transport, health and law enforcement. Each state is also responsible for planning and major infrastructure and service delivery in the state's dominant urban regional area so that, in this sense, the states are the primary 'metropolitan managers' [36, p. 5].

Local government is the third tier of government in Australia, although it is not recognized in the federal Constitution. Since Federation in 1901, Australian local government's key relationship has been with the state governments, based on 'the constitutional and legal frameworks, state oversight and control of local government activities and the close interrelationships between state and local government responsibilities for service delivery and infrastructure' [37, p. 22). Each state government defines the powers of its local governments, and decides for which geographical areas those local authorities are responsible. This third tier of government is consequently legislatively established at the State and Territory (second-tier) level. In New South Wales, for example, the Local Government Act 1993 stipulates:

A council may provide goods, services and facilities, and carry out activities, appropriate to the current and future needs within its local community and of the wider public, subject to this Act, the regulations and any other law. [New South Wales Local Government Act 1993, Section 24]

This fairly 'open' interpretation of functions provides opportunities and constraints for local governments to be the institutional representation of democracy at the local level. Citizens in designated local jurisdictions elect representatives to serve as their local councilors, and in some cases directly elect the Mayor. These elected representatives serve as the policy-making arm of local government, while the management and administration is performed by a multi-faceted workforce. Local government in Australia functions within a multi-party democracy, underpinned by the rule of law and an independent judiciary. All of these suggest opportunities. At the same time, and as will be explored further in this chapter, local government is constrained due to its relatively weak position as a tier of government within the Australian federal model.

\section{Other contextual conditions}

Other key contextual conditions to take into consideration include: 
- Firmly within the liberal democratic tradition, there is a strong focus in Australia on the rule of law, an independent judiciary and freedom of the press.

- Civil society is active and influential. Public consultation by all levels of government is taken seriously, albeit not always delivered consistently or effectively.

- While the federal government in particular takes an active role in wealth and income redistribution - and there is a functioning social security system that shifts between right-of-center and left-of-center approaches toward the welfare state in tandem with political shifts in an essentially two-party system - the private/corporate sector is a powerful actor. Issues of privatization and 'small government' are regularly in the public debate.

\section{Structural Conditions}

The focus in this section is on the position of local government vis-à-vis other governments and on the degree of decentralization in the Australian Federation. A key feature of the Australian model of federation is the extent of the 'imbalance in the revenue raising capacities and spending responsibilities of the different tiers of government', which is described as 'vertical fiscal imbalance' [29, p. 22]. Income tax is levied federally - over $90 \%$ of Commonwealth revenue is sourced from taxation, and the amount it raises in revenues exceeds its spending responsibilities. At the same time, State and Territory governments have insufficient revenue from their own sources to finance their spending responsibilities. Total Commonwealth funding to the States and Territories represents around one quarter of the Commonwealth budget and $40 \%$ of the revenue of the second tier [29, p. 22].

Debates and practices relating to fiscal decentralization, that is, the devolution of authority for public finances and the delivery of government services from the national to sub-national levels, has primarily been focused on the relations between the federal government and the second-tier (State and Territory) governments. There has been no concerted policy direction in recent years to devolve greater levels of responsibility for policy making, management, and implementation of national goals to the third tier. At the same time, there has been concern about 'cost-shifting', that is the transfer of more service delivery responsibilities to local government from other spheres of government without appropriate resources, and thus reducing the ability of local governments to focus their own revenues on the priorities of their communities [22, p. 24].

Australia has needed to focus on the relationship between the national and subnational governments within its federal system, which has developed in a dynamic way over the decades in response to political, economic, demographic and international changes. Fenna and Hollander [18, p. 225] point out that the Constitution makes little provision for intergovernmental relations... [but]...considerable need now exists for cooperative and collaborative action'. The Council of Australian Governments (COAG) is the key intergovernmental forum in Australia. Its members are the Prime Minister, State and Territory Premiers and Chief 
Ministers and the President of the Australian Local Government Association (ALGA).

Under the auspices of COAG, the Intergovernmental Agreement on Federal Financial Relations came into effect with the passing of the Federal Financial Relations Act 2009 [18: p. 225]. This Agreement currently provides the overarching framework for the Commonwealth's financial relations with the States and Territories. While the States/Territories have increased budget flexibility under the revised federal financial relations framework, they are also subject to greater accountability through new reporting arrangements. One consequence has been a proliferation of National Agreements and National Partnerships on key public issues such as education, health and employment. In particular, there is a range of Agreements relating to 'closing the gap' between Indigenous and non-Indigenous Australians, briefly discussed earlier as one of the key socio-economic challenges of the country.

\section{Institutional Conditions of the Local Government Sector}

Local governments in Australia exhibit considerable diversity, not only in terms of the state-based legislative frameworks within which they operate, but also due to their size, the demographic, geographic and economic attributes of their LGAs, their financial capacities, the preferences and expectations of their local communities, and the management capacity and skills base of their elected representatives (councilors) and staff [35, p. 10-12].

While many local governments in urban areas have populations of 100,000 or more $^{2}$, around 200 local governments serve populations of less than 10,000 residents. Local governments range in size from a few square kilometers in some metropolitan areas to thousands of square kilometers in remote parts of the country ${ }^{3}$. The number of local governments in Australian state jurisdictions is summarized in Table 2.

Due to structural reform in the various state jurisdictions, the trend over the past hundred years has been towards consolidation, and hence towards fewer individual local governments. This trend is ongoing and, for example, a current large-scale process of local government amalgamations in Western Australia - accompanied by wide community consultation and media attention - will influence the size and number of local governments in that jurisdiction in the near future. A similar process has recently been initiated in New South Wales.

\footnotetext{
${ }^{2}$ Brisbane City Council in Queensland is the most populous, with a population of $1,052,458$.

3 The largest is East Pilbara in Western Australia, covering an area of 371,696 square kilometres, with a population of 7,954 .
} 
Table 2. Number of local governments in Australia (2014)

\begin{tabular}{|l|c|c|c|}
\hline Jurisdiction & $\begin{array}{c}\text { Greater Capital City } \\
\text { Area }\end{array}$ & $\begin{array}{c}\text { Non-Capital City } \\
\text { Areas }\end{array}$ & Total \\
\hline New South Wales & $43^{4}$ & 109 & 152 \\
\hline Victoria & 31 & 48 & 79 \\
\hline Queensland & $10^{5}$ & 63 & 73 \\
\hline Western Australia & 31 & 108 & 139 \\
\hline South Australia & 17 & 51 & 68 \\
\hline Tasmania & 6 & 23 & 29 \\
\hline $\begin{array}{l}\text { Northern } \\
\text { Territory }\end{array}$ & 3 & 13 & 16 \\
\hline Total & 141 & 415 & 556 \\
\hline
\end{tabular}

Source: authors, drawing on data on local governments in State/Territory jurisdictions as at January 2015

\section{Functions}

In contrast to many other, Australian local government has a relatively narrow range of functions. Initially, it acted as the primary mechanism to transfer to the community the 'administrative and financial burden for the provision of basic local services' [6, p. 5). Services to property were at the core of its responsibilities, with provision of local roads being the most prominent ${ }^{6}$. Following the Second World War, local government functions broadened to include town planning and a range of welfare, environmental protection and leisure services.

The past few decades have been marked by expansion of local government functions and there has been a shift in emphasis in service provision away from the traditional focus on 'services to property' towards a more expansive 'services to people' orientation [16, p. 280]. This has been partly due to devolution of roles and responsibilities by other spheres of government, but also due to market deregulation; industrial relations reform; the privatization of public utilities; competition policy; technological advancement; and expanding service provision in response to community demands [6, p. 7]. Key service areas that are common to local

\footnotetext{
${ }^{4}$ This number includes the LGAs in the Blue Mountains and the Central Coast, which have close links to the Greater Sydney Metropolitan region, also as dormitory cities.

${ }^{5}$ This includes all the LGAs of the South-east Queensland region in which Brisbane, the capital city, is located.

${ }^{6}$ As of 2011, Australia's total road network length was $911,418 \mathrm{~km}$, with local councils being responsible for the majority - approximately 670,000 km - of roads (ALGA 2014).
} 
governments throughout the country at the present time, whether as provider, contractor and/or coordinator, are summarized in Table 3.

Table 3. Services provided by local government in Australia

Service category

\section{Engineering and \\ infrastructure}

Property-related

Administration, regulation and planning

Environment and health

Community and social

Recreation, cultural and education

\section{Service examples}

Public works design, construction and maintenance of local roads, bridges and footpaths, drainage, waste collection and management, water supply

Domestic waste management, including solid waste and recycling

Land use and town planning, development approvals, building inspection, licensing, administrative functions related to cemeteries, parking stations and street parking

Catchment management, parks and gardens, tree removal, pest and weed control, public toilets, noise control, animal control

Aged services, child care services, youth centers, community housing facilities, counselling and welfare services, arts and cultural development

Libraries, swimming pools, recreation centers, community halls, sports facilities, camping grounds, community festivals, museums

Other

Abattoirs, bus services, livestock sale-yards, markets

Source: Productivity Commission [35, p. xx]

As is evident from the description of service categories and service examples in Table 3, local government in Australia delivers substantial levels of public services and manages considerable economic activity. Australian local governments generally have responsibility for a homogenous stock of assets including the local road network (more than half the total stock by value), bridges, storm water and drainage systems, swimming pools, parks and community centers. Some local governments are also responsible for managing local water supply and wastewater, waste management facilities, and regional airports.

\section{Assets and Finance}

In 2011-12, according to data from the Australian Bureau of Statistics, Australian local governments raised $\$ 37$ billion in revenue, spent $\$ 31$ billion, and invested a net additional $\$ 5$ billion in its infrastructure assets [7, p. 3). A summary of revenue and expenditure for 2011-12 is provided in Box 1. 


\section{Box 1. Australian local government revenue and expenditure in 2011-12}

\begin{tabular}{|c|c|}
\hline \multicolumn{2}{|c|}{ Revenue (totaling \$37 billion) comprised: } \\
\hline & $\$ 13.2$ billion in tax revenue ( $36 \%$ of total) \\
\hline & $\$ 9.2$ billion of 'other' revenue, such as capital grants and infrastructure levies for new \\
\hline \multicolumn{2}{|r|}{$\begin{array}{l}\text { upgraded assets (this has grown over the decade from } 2002-03 \text { from } 16 \% \text { to } 25 \% \text { of general } \\
\text { revenue) }\end{array}$} \\
\hline & 49.0 billion in sales of goods and services ( $24 \%$ of total) \\
\hline & $\$ 4.3$ billion in current grants and subsidies ( $12 \%$ of total) \\
\hline & $\$ 1.2$ billion in interest ( $3 \%$ of total) \\
\hline \multicolumn{2}{|r|}{ Expenditure (totaling $\$ 31$ billion) included: } \\
\hline & $\$ 7.3$ billion on transport and communications ( $24 \%$ of total) \\
\hline & $\$ 6.9$ billion on housing and community amenities ( $22 \%$ of total) \\
\hline & $\$ 5.6$ billion on general public services ( $18 \%$ of total) \\
\hline & $\$ 4.6$ billion on recreation and culture ( $15 \%$ of total) \\
\hline & $\$ 1.7$ billion on social secur4ityy and welfare (5\% of total) \\
\hline & $\$ 633$ million in debt repayments ( $2 \%$ of total). \\
\hline
\end{tabular}

Source: Carter [7, p. 3]

According to Carter [7, p. 4], Australian local government is 'asset rich and income poor' and the sector's total income of about $\$ 37$ billion is 'dwarfed' by the billions of dollars in fixed assets it needs to manage and maintain. Nationally, the value of total land and fixed assets of local government in 2012-13 was $\$ 333$ billion, of which local roads infrastructure constituted $\$ 165$ billion [5]. The Australian Bureau of Statistics estimates that these assets grew at the rate of $7.4 \%$ between 2002 and 2012 [17, p. 13].

Local government revenue comprises own-source revenues and grants from other tiers of government. Own-source revenue derives from taxation on property (about 37 percent of total revenue), user charges, income from public enterprise and fines, and interest on investments and dividends [35: p. xxvii]. Factors affecting own-source revenue per person raised by local governments include the size of the population and population growth, the number of properties serviced per person, personal income of residents, business income, total length of the local road network (greater length representing higher expenditure needs), and the class of the council. The latter reflects in part the preferences and needs of classes of local communities as well as differences in the cost of services across geographic locations [35, p. xxvii].

Federally-provided revenue is the most import source of external funding for local governments [37, p. 20], accounting for around 12\% of aggregate local government income [7, p. 4]. The federal government financially supports local government by means of 'untied' Financial Assistance Grants (in keeping with the Local Government (Financial Assistance) Act 1995) and 'tied' Specific Purpose Payments. Financial Assistance Grants are distributed on the basis of recommendations made by the Commonwealth Grants Commission, operating under 
the Grants Commission Act 1973. The grants are paid to the States/Territories and in turn passed onto local governments. The most significant Specific Purpose Payment has been the Roads to Recovery program to assist in the construction and maintenance of extensive local road networks.

The grants, first introduced in the mid-1970s, have aimed to reduce the vertical fiscal imbalance discussed earlier; and to promote horizontal equalization between the more and less financially secure local governments. Funds are distributed to local governments via the states' Local Government Grants Commissions. Around twothirds of total funding is allocated to non-metropolitan areas, where the local councils are generally in greater need [37, p. 20-21].

\section{Knowledge and Sources of Information}

Key sources of knowledge and information that contribute to the local government include:

- The Australian Bureau of Statistics conducts the five-yearly Census of Population and Housing, as well as making publically available a range of data under its 'Local Government Portal', including population, economic and social statistics [3].

- The Council on Federal Financial Relations is responsible for maintaining a register of national minimum data sets to allow comparative reporting of governments' achievements against agreed objectives and outcomes [10].

- The Productivity Commission, the Australian Government's independent research and advisory body, conducts 'public inquires at the request of the Australian Government on key policy or regulatory issues bearing on Australia's economic performance and community wellbeing' [33, p. 3].

- Research-based expertise is provided through organizations such as the Australian Centre of Excellence for Local Government (UTS:ACELG) located at the University of Technology, Sydney and other university-based public administration, political science and economics faculties.

- Local governments tender out or conduct their own research, including community profiles, community satisfaction surveys and evaluations of programs.

\section{Human Resource Conditions}

Key data on human resource conditions in Australian local government are provided from the recently-conducted Australian Local Government Workforce and Employment Survey [20]. Local government employs a large and diverse workforce that comprises around $10.2 \%$ of the total public sector - as of 2013, there were 192,500 people working in Australian local government, out of a total of 1.8 million public sector employees nationally. Compared to the Australian labor force average of $29 \%, 37 \%$ of employees in local government are aged 50 years or over, and males are on average older than female employees. Local governments employs a large number of Aboriginal and Torres strait Islander people - while local government 
employees represent only $9 \%$ of the total public service workforce, $22 \%$ of all Indigenous public sector workers are employed by local government. Employees of local governments have higher levels of educational attainment than the allindustries-workforce across Australia, with $65 \%$ of men and $70 \%$ of women in local government having a post-school qualification compared to the national average of only $45 \%$. In areas where local government has difficulty recruiting staff due to skills shortages, it is also often in competition with other industries for these workers. Vacancies are higher for engineers, planners, child care staff, environmental health workers, surveyors and managers.

There is a diverse range of roles, responsibilities and activities required by local government to efficiently and innovatively deliver the range of local services that satisfy community and stakeholder needs and 'without an effective local government, local economies and communities would struggle to operate, especially in regional Australia' $[25 ; 20$, p. 22]. The range of occupations employed by Australian local government can be classified into four main streams, illustrated in Figure 3 with examples of occupational categories:

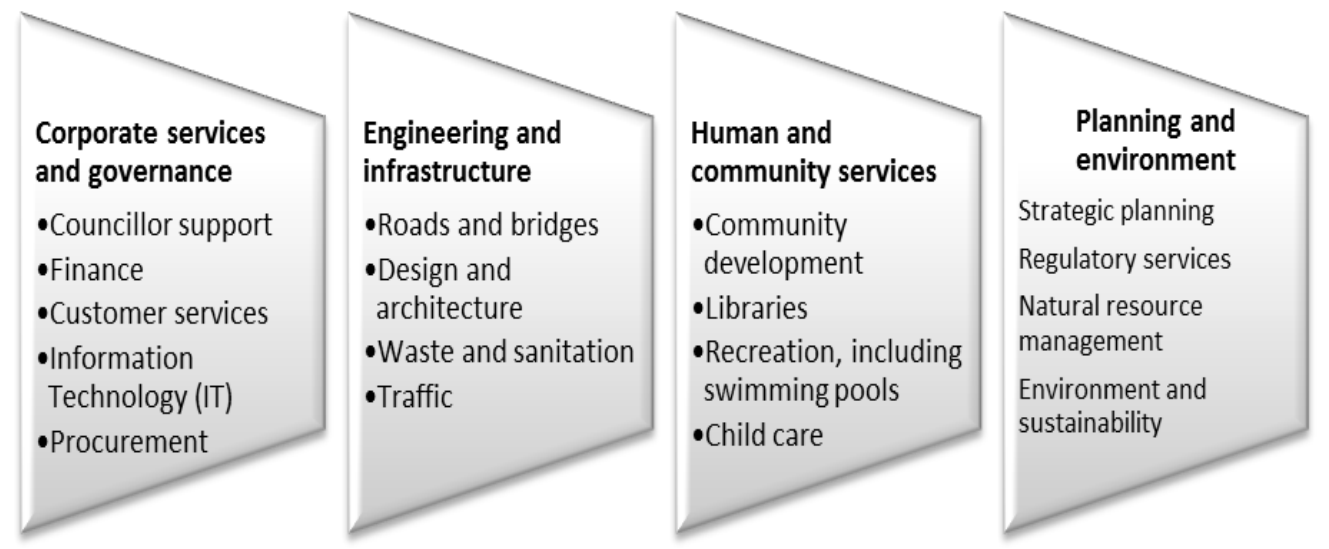

Figure 2: Local government workforce occupational groupings

Source: adapted from LGMA and ACELG [25, p. 24-25].

A feature of the workforce situation in the country is the active involvement of professional membership-based organizations, such as Local Government Managers Australia, the Australian Business Excellence Network and the Institute of Public Works Engineering Australasia. These operate at a national level, as well as in the States and Territories. Professional development and graduate training is available to people who work in the sector, and, for example, UTS: ACELG offers training and development for councilors to better understand their legislative responsibilities and build their skills and capacity to have a positive impact on council decision-making. This is in addition local government studies at graduate level that provide teaching/learning on subjects including research, organization and management, leadership, strategic planning and comparative local governance. 
As a sector, local government is supported by national and state-based local government associations, who provide networking, training and advocacy services to their members [5].

\section{Recent Attempts to Improve Local Government Capacity}

Local government in Australia is under ongoing pressure to evolve in order to address challenges such as financial sustainability, changing community needs and expectations, metropolitan growth and shifting relationships with federal and state governments [2, p. 9-10]. A potential gap between expectations and resourcing to carry out necessary functions within the Federation remains one of the prime concerns with regard to local government capacity in Australia. Ongoing reforms have aimed 'to improve some aspect of the structure, performance or accountability of local government' [19, p. 3-4]. Recent reforms have focused on, amongst others:

- Structural reforms - changes to the boundaries, numbers and types of local governments

- Functional reforms, including the alignment of functions between local government and other tiers of government

- Changes to the financial circumstances of local government, including changes to revenue sources, expenditure and financial management

- Changes to the administrative, executive and management processes of local governments, including performance management and performance monitoring and reporting.

\section{Structural Reform}

Structural reform, which includes mechanisms such as closer collaboration amongst local governments, shared service arrangements, boundary changes and mergers, has been a key strategy adopted by State and Territory governments in order to reform local government. Cost savings due to economies of scale have often been seen as the prime motivation for such reforms, which are ongoing [2]. Questions of representation and local democracy, and the loss of local identity that may follow amalgamation are important aspects of an often vigorous debate and research is continuing in respect of the impact and outcomes of these structural reforms.

Despite difficulties with, and opposition to, reforms that may lead to the consolidation of local government jurisdictions, there is growing acceptance in the local government sector that enhanced strategic capacity is important. Due to factors such as increased size and resourcing levels, pooling of knowledge and expertise, and encouraging a focus on operating in a broader regional and system-wide context enhanced capacity appears essential to its long-term success as a valued partner in the federal system of government [2] and in the face of changing capacity required for an enhanced governance role. 


\section{Accountability Within the Federation}

Notwithstanding its relatively weak constitutional and legal position, local government in Australia has made some progress towards its acceptance as a partner in the federal system. This is due in no small measure to the growing power of the Australian Government vis-à-vis the states as a result of High Court decisions, income taxing powers and revenue capacity, key referenda results and the policy objectives of governments, particularly the federal government [13, p. 7]. The Public Governance, Performance and Accountability Act 2013, which came into effect on 1 July 2014, is intended to modernize and simplify the financial, accountability and audit obligations of government agencies and departments. It is based on four key principles:

- Government should operate as a coherent whole

- Uniform duties should apply to all resources handled by Commonwealth entities

- Public sector performance is more than financial

- Engaging with risk is a necessary step in improving performance.

As noted earlier in this chapter, local government is not an equal partner with the Commonwealth and States/Territories in terms of inter-governmental debates and agreements, and yet, at the community engagement and implementation level, it is difficult for higher tiers of governments to meet targets without involvement of local communities and local governments. There have been attempts to have local government formally recognized in the federal constitution, including plans for a national referendum on the issue in 2013/14, but, as has often occurred in the past, the impetus for this waned, giving further support for the view that l'local government's emergence on the federal scene is presently not guaranteed and could be reversed at any time if federal and state governments were to agree on such a course" [37, p. 29].

It may also be argued that constitutional recognition of local government would not alter substantially the role and standing of local government within the federation. The latest initiative with regard to broader reform has been progress towards a 'White Paper on Reform of the Federation', which has the objectives of achieving a more efficient and effective federation and, in so doing improve national productivity [13]. Since the 'White Paper' is expected to be delivered by the end of 2015, the impacts of this reform, including potential impacts on local government, are unclear at the time of writing.

The regulatory framework governing the activities and performance of local governments is similar in the different state and territory jurisdictions, including that they each have a Local Government Act and supporting legislation, a ministry, division or department of local government (and in some cases of regional affairs), and a Local Government Grants Commission and ancillary regulatory bodies [16, p. 280]. Research and reporting, and the accountability it enables, is consistent and reliable in the country, although improvements are always desired and encouraged, 
highlighting the point that capacities in strategic planning, research, reporting, finance and asset planning are necessary for the functioning of councils in their communities.

\section{Performance Reporting}

All local governments in Australia have the legal requirement to report on their performance to their respective state government in the form of Annual Reports, performance statements and financial statements. The model in the state of Victoria represents a new level of sophistication in local government performance monitoring and reporting in Australia, and is briefly described in Box 2.

\section{Box 2. Performance Reporting and Accountability in Victoria}

The Local Government Act 1989 (Victoria) is the main legislative instrument for Victoria's 79 local governments. The Local Government Amendment (Performance Reporting and Accountability) Act 2014 sets out the new financial planning and reporting framework for local government, commencing in the 2014-15 financial year. The Framework comprises indicators that measure performance across three thematic areas, namely service performance, financial performance and sustainability. To provide a comprehensive picture of local government performance, four indicator sets were developed across the three thematic areas. These indicator sets are:

- Service Performance (quantitative measures)

- Financial Performance (quantitative measures)

- Sustainability (quantitative measures)

- Governance and Management (qualitative measures).

It is noteworthy that this indicator framework has gone through several iterations (currently version 4), suggesting that the development of performance monitoring and reporting frameworks, especially the indicator sets that are used, is a process that requires ongoing revision and refinement, as well as the capacity to engage in such a process.

Key aspects of this process have included the need for reform established through a government audit; involvement of key stakeholders - State government, local governments, and local government peak bodies - in the development of the framework; establishment of a legislative basis; and cumulative development of the framework, including discussion papers, drafting and consultation, and refinement and further refinement of the metrics (e.g. the indicators) used in the models, suggesting that these all take time to develop.

Source: adapted from Local Government Victoria [26]; Victorian Government [40].

\section{Strategic Planning}

There are differences in the nature and scope of strategic planning in the various jurisdictions, but common components include long-term Community Strategic Plans that are based on sound engagement of the local government within its community and progress on which is reported back to the community via Annual Plans; Corporate and Workforce Plans; and Financial and Asset Management Plans. Examples of the diversity evident in the different jurisdictions is that, in Queensland, regional as well as local issues are considered in the long-term Community Plans; and 
in South Australia, the local governments have to show in their strategic planning that their activities are aligned with those of the other levels of government. The strategic planning framework adopted in the most populous state, New South Wales, is described in greater detail in Box 3.

\section{Box 3. The Integrated Planning and Reporting Framework in New South Wales}

Amendments to the Local Government Act 1993 (New South Wales) led to promulgation of the Local Government Amendment (Planning and Reporting) Act 2009 that required local governments to adopt robust financial planning and reporting practices in responding to their communities' needs. All local governments in this most populous state of Australia are required to prepare a suite of integrated documents, the preparation of which requires extensive community consultation guided by a community engagement strategy. This is known as the Integrated Planning and Reporting Framework.

The Community Strategic Plan identifies the main priorities and aspirations for the future of the local government area covering a period of at least ten years from when the plan is endorsed; and establishes strategic objectives together with strategies for achieving those objectives. Each local government needs to ensure that the Community Strategic Plan addresses civic leadership, social, environmental and economic issues in an integrated manner; is based on social justice principles of equity, access, participation and rights; is adequately informed by relevant information relating to civic leadership, social, environmental and economic issues; and is developed having due regard to the State Plan and other relevant state and regional plans of the New South Wales Government.

A resourcing strategy identifies responsibility in terms of the issues identified in the Community Strategic Plan. The resourcing strategy focuses in detail on matters that are the responsibility of the local government and comprises: a ten year financial plan; a ten year asset management strategy; and a four year workforce development plan. A four-year delivery program translates the community's strategic goals into actions within the resources available under the resourcing strategy. The Annual Operational Plan supports the delivery program and spells out the individual projects and activities that will be undertaken to achieve commitments made in that program.

Source: adapted from Tan and Artist [38]

Western Australia has adopted a similar system of integrated planning and reporting as the model developed in New South Wales.

\section{Financial Performance and Capacity}

Comrie [8] classifies factors that have raised interest in local governments' financial performance and capacity in recent decades as follows:

- An increased range of responsibilities, but without revenues keeping pace with expenditure requirements

- Demands and implication of demographic change - additional infrastructure needs and service level pressures in many local governments in urban and coastal localities that have experienced rapid population growth, and financial challenges for local government in many rural and regional communities that have experienced population and income loss 
- Concern that local government assets are aging and that renewal expenditure is not occurring at the rate necessary to maintain service levels

- Volatility in the local taxes (rates) paid by many ratepayers.

This has led to the observation by commentators such as Dollery, Kortt and Grant $[15$, p. 81] that 'Australian local government has become victim to worsening financial sustainability and the emergence of a massive infrastructure backlog'. At the same time, there is evidence that, taking all of the local governments in Australia as a whole, revenue slightly exceeds operating expenses and that local government liabilities are modest as a percentage of total assets $(5 \%)$ and as a percentage of total annual revenue (44\%). In other words, the sector has negative net financial liabilities [8, p. 9-11].

Most recently steps have been taken by the federal government and local governments to assess the status of local government financial and asset management, and a national approach to the issue has been adopted, by pulling together information from state-based data and creating national data. Prior to this, in the mid-1990s, amendments to local government acts obliged local governments to change from cash accounting to accrual accounting, which 'values assets according to their replacement cost, not their historical cost [requiring]...provisions for the cost of restoring ageing assets to a sound operating condition' [7, p. 9]. Still, local governments were slow to move from a 'balanced budget' mindset, and Comrie [8] has recommended that the sector consider using debt instruments more broadly as a means to deal with infrastructure backlogs. There is currently work underway to better assess the state of assets in a manner which is more realistic. This approach is likely to lead to an overall reduction in the estimated value of infrastructure backlogs [5].

The ability of the sector to accelerate new investments is constrained by a perceived limited access to capital, the absence of projects of sufficient scale and the use of methods of procurement that do not involve significant ongoing maintenance and operation activities [17, p. 60]. Dollery et al [15] show support for the establishment of a national collective financing vehicle for the local government sector that could address this suboptimal use of debt. The Local Government Finance Authority of South Australia, which has been functioning since 1984 as a municipal bond bank, provides an example of a state-based borrowing and investment program for the benefit of councils and prescribed local government bodies that could serve as model for a nation-wide institution.

\section{Rural-remote and Indigenous Local Governments}

The great diversity in the geographic and population size of local governments in Australia has been referred to earlier. As a key example of this institutional diversity, rural-remote and Indigenous (RRI) local governments in the vast and sparselypopulated interior of the continent are often obliged to assume responsibility for local services that are delivered in urban municipalities by state and federal government agencies or by organizations in the private sector [16, p. 280]. In regional and remote areas, local government employs a larger proportion of the workforce than most other 
industries, with the exception of health care, social assistance and education [20, p. 9].

While Australian local government commonly faces challenges such as critical skills shortages, problems with recruitment and retention of staff, infrastructure backlogs, and increasing service demands from communities, ACELG through its Rural-remote and Indigenous Local Government Program has identified a group of 105 RRI local governments where such challenges are significantly magnified due to:

- Geographic size - these 105 Councils account for $65 \%$ of Australia's total land mass

- Geographic isolation, low populations, and a higher proportion of Indigenous people

- A higher proportion of workers who do not make their places of employment their communities of residence, and consequently commute over long distances

- A high demand for community services normally delivered by other tiers of government

- Large infrastructure maintenance requirements

- High financial dependence on grants from higher tiers of government.

This led to the development of a national capacity-building strategy launched in 2011 [28]. Key priorities for RRI local government include:

- Aiming for a shared understanding of the 'core' local government responsibilities that can be delivered sustainably by RRI local governments and against which actual services provided can be assessed

- Tailored information technology, finance, management and communications systems

- Training and support for improved financial and asset management literacy and practices of elected members and council staff

- Appropriate governance training and practices for councilors and staff, including education for the community on the roles and responsibilities of local government and councilors to parallel the governance training of councilors and staff

- Maximized regional collaboration and resource sharing, including developing case studies of successful practice.

Key activities since the launching of the capacity-building strategy have included scoping studies (such as on community engagement and local government service delivery), developing case examples, sharing information and lessons learned through networks, and delivering learning programs to the local government sector, particularly in rural and remote regions [28].

\section{Human Resources}

According to LGMA and ACELG 2013 report main current local government workforce challenges include especially skill shortages in some occupations that are critical to the functioning of local government, and challenges in attracting and retaining skilled staff, a widespread problem of the ageing of the workforce and 
inadequate succession planning associated with the expected widespread retirement of mature workers, an increasing need for higher qualifications and technological changes require the workforce to continuously upgrade its qualifications and skills.

ACELG was requested in 2010 to develop a local government workforce strategy and follow-up actions with respect to sustainability, based on funding provided by the Australian Government. This included the design and initial collection of a National Minimum Data Set and the development of a National Assessment Framework for asset and financial management [25]. Based on a program of research and consultations, a National Local Government Workforce Strategy was put forward that is designed to move the sector towards a more sustainable workforce through adoption of the following strategies and actions (Figure 3).

Figure 3. Key elements of the Local Government National Workforce Strategy

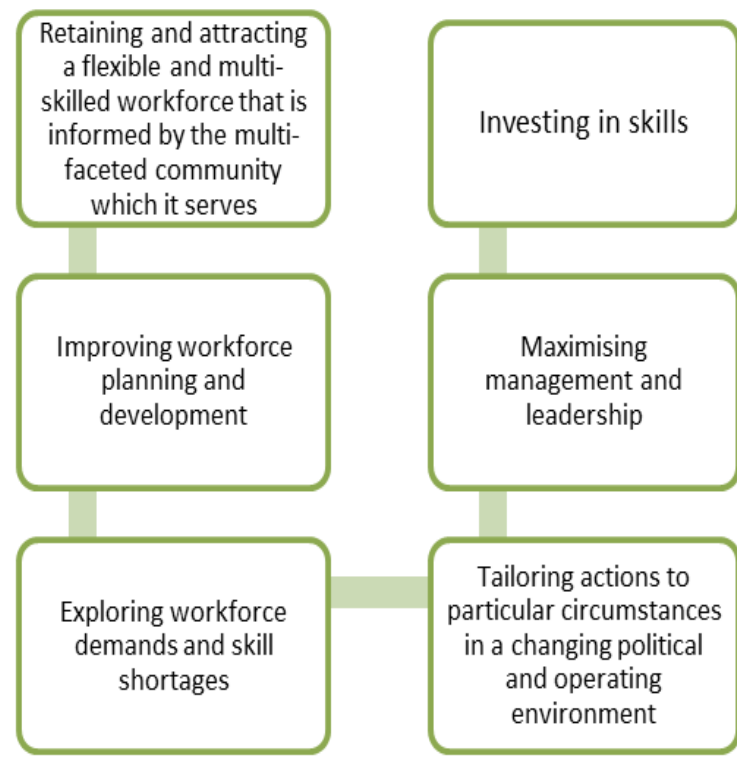

Being responsive to the needs and desires of the current and potential workforce through, for example, encouraging job sharing and flexible working hours

Embracing and investing in technology to increase workplace productivity

Promoting local government as a placebased employer of choice

Source: adapted from LGMA and ACELG [25].

As noted earlier in this chapter, local government is a significant employer nationally, and particularly so in regional and remote areas. Strengthening the local government sector represents an opportunity to secure and strengthen the economic, environmental and social foundations of many communities in Australia [20, p. 37].

An important human resource issue in Australian local government relates to the importance of leadership as discussed earlier in this chapter, and specifically the relationship between the Mayor, as leader of the elected council, and the chief executive officer (CEO) or general manager leading the council organization. Recent research suggests that local government capacity is enhanced when this relationship 
effectively on focuses on challenges, based on having a sense of purpose, a clear and well-articulated vision, a facilitative leadership style and a willingness to share the honor of serving the community they represent with others [27, p. 21]. This remains a focus of local government capacity building in Australia.

\section{Conclusion}

1. Appreciation of historical antecedents, opportunities and constraints: From its origins as administrative arm of state government, with a traditional focus on 'services to property', there has been a shift to a more expansive 'services to people' and now a governance orientation for local government. The local government sector's position in the Australian Federation still remains weak. Local government's primary relationship remains with the states, and there has been no concerted policy direction in recent years to devolve greater levels of responsibility for policy making, management, financial autonomy and implementation of national goals to the third tier of government.

2. Current governance capacity: A potential gap between expectations and resourcing to carry out necessary functions within the Federation remains one of the prime concerns with regard to local government capacity in Australia. The workforce is highly educated on the whole, but there are skills shortages in key areas and the sector is facing problems with the aging of the workforce. Local governments in Australia exhibit considerable diversity, and there are different opportunities and challenges for metropolitan and other urban municipalities compared to local governments in regional, rural and remote areas. In many rural and remote communities, local government is a major employer, the primary economic driver and the only level of government delivering basic social and community services. Capacity has recently been enhanced by focusing on effective long-term financial and asset management, a renewed emphasis on strategic planning and performance reporting, and structural reforms, which include mechanisms such as closer collaboration amongst local governments, shared service arrangements, boundary changes and mergers. Efficient and effective capacity in a local governance milieu focuses more and more upon explicit functioning within a governance context and there is a growing recognition that this places emphasis on networking and collaborative capabilities, underpinned by sound public service and democratic principles.

3. Capacity to take on additional challenges and responsibilities: There is growing acceptance in the local government sector that enhanced strategic capacity linked to factors such as increased size and resourcing levels, pooling of knowledge and expertise, and encouraging a focus on operating in a broader context appears essential to local government's long-term success as a valued partner in the federal system of government. Capacity-building requires a skill set and enhanced capabilities at both local political and administrative levels, underpinned by greater levels of collaboration within the sector, and a consistent focus on being the strategic enablers for local communities. In order to set the agenda and facilitate local solutions 
to local problems, there is a need to retain and attract a flexible and multi-skilled workforce that is informed by the multi-faceted community which it serves. Leadership and management capacity is crucial in this regard and, in this quest for enhanced capacity, local government as a sector is supported by national and statebased local government associations, an established and continuously improving tradition of research and reporting, and a growing emphasis on education and training for both elected local politicians and for local government personnel.

\section{References}

1. Abbot, J. 2013. Collaborative Governance and Metropolitan Planning in South East Queensland - 1990 to 2010: From a Voluntary to a Statutory Model. ACELG, University of Technology, Sydney.

2. Aulich, C, Gibbs, M, Gooding, A, McKinlay, P, Pillora, S and Sansom, G. 2011. Consolidation in local government: A fresh look - Volume 1: Report. ACELG, University of Technology, Sydney.

3. Australian Bureau of Statistics. $2015 . \quad$ Population, http://www.abs.gov.au/ausstats/abs\%40.nsf/94713ad445ff1425ca25682000192af2/16475 09ef7e25faaca2568a900154b63? OpenDocumentm, accessed January 2015.

4. Australian Government. 2014. Australia.gov.au - helping you find government information and services, http://australia.gov.au/, accessed January 2015.

5. Australian Local Government Association [ALGA]. 2014. Facts and figures on local government in Australia, http://alga.asn.au/?ID=59, accessed January 2015.

6. Brackerz, N. 2013. Political actor or policy instrument? Governance challenges in Australian local government. Commonwealth Journal of Local Governance, Issue 12: 319.

7. Carter, M. 2013. Briefing Paper: Australian local government financial reform - A federal perspective. ANZSOG Institute of Governance, Canberra and ACELG, University of Technology, Sydney.

8. Comrie, J. 2013. In Our Hands: Strengthening local government revenue for the $21^{\text {st }}$ century. ACELG, University of Technology, Sydney.

9. Council of Australian Governments. 2011. Intergovernmental Agreement on Federal Financial

Relations, http://www.federalfinancialrelations.gov.au/content/inter_agreement_and_schedules/IGA _federal_financial_relations_aug11.pdf, accessed January 2015.

10. Council on Federal Financial Relations. 2014. Register of National Minimum Data Sets, http://www.federalfinancialrelations.gov.au/content/national_minimum_data_sets.aspx, accessed January 2015.

11. Cuthill, M. and Fien, J. 2005. Capacity building: Facilitating citizen participation in local governance. Australian Journal of Public Administration, 64(4): 63-80.

12. Denters, B. and Rose, L.E. 2005. Local governance in the Third Millennium: A brave new world? In: B. Denters and L.E. Rose [Eds.]. Comparing Local Governance: Trends and Developments. Palgrave Macmillan, Houndmills, Basingstoke, UK: 1-13. 
13. Department of the Prime Minister and Cabinet. 2014. Reform of the Federation White Paper: A Federation for our future, Issues Paper 1, https://federation.dpmc.gov.au/sites/default/files/issues-

paper/issues_paper1_a_federation_for_our_future.pdf, accessed January 2015.

14. Department of Social Services. 2014. The People of Australia - Australia's Multicultural Policy, https://www.dss.gov.au/our-responsibilities/settlement-and-multiculturalaffairs/publications/the-people-of-australia-australias-multicultural-policy, accessed January 2015.

15. Dollery, B., Kortt, M. and Grant, B. 2013. Funding the Future: Financial sustainability and infrastructure finance in Australian Local Government. The Federation Press, Sydney.

16. Dollery, B., O'Keefe, S. and Crase, L. 2009. State oversight models for Australian local government. Economic Papers (Journal of the Economic Society of Australia), 28(4): 279-290.

17. Ernst and Young. 2012. Strong foundations for sustainable local infrastructure: Connecting communities, projects, finance and funds. Report prepared for the Department of Regional Australia, Local Government, Arts and Sport. Ernst and Young, Australia.

18. Fenna, A. and Hollander, R. 2013. Dilemmas of federalism and the dynamics of the Australian case. Australian Journal of Public Administration, 72(3): 220-227. Gooding, A. 2013. Review of current local government reform processes in Australia and New Zealand. ACELG, University of Technology, Sydney.

19. Hastings, C., Ryan, R., Gibbs, M. and Lawrie, A. 2014. Profile of the Local Government Workforce 2014 Report. ACELG, University of Technology, Sydney.

20. Honadle, B.W. 2001. Theoretical and practical issues of local government capacity in an era of devolution. The Journal of Regional Analysis and Policy, 31(1): 77-90.

21. Jones, S. 2008. Can Australian local governments have a role in local economic development?: Three cases of evidence. Urban Policy and Research, 26(1): 23-38.

22. Kelly, A.H., Dollery, B. and Grant, B. 2009. Regional development and local government: Three generations of Federal intervention. Australasian Journal of Regional Studies, 15(2): 171-193.

23. Larcombe, F.A. 1973. The Origin of Local Government in New South Wales 1831-58: A History of Local Government in New South Wales Volume 1. Sydney University Press, Sydney.

24. LGMA (Local Government Managers Australia) and ACELG (Australian Centre of Excellence for Local Government). 2013. Future-proofing Local Government: National Workforce Strategy 2013-2020. http://www.acelg.org.au/national-local-governmentworkforce-strategy-0, accessed January 2015.

25. Local Government Victoria. 2014. Local Government Performance Reporting Framework - Indicator Workbook Version 4.0. Government of Victoria, Department of Transport, Planning and Local Infrastructure, Melbourne. 
26. Martin, J. and Aulich, C. 2012. Political management in Australian local government: Exploring roles and relationships between Mayors and CEOs. ACELG, University of Technology, Sydney.

27. Morris, R. 2011. A Capacity Building Strategy for Rural-Remote and Indigenous Local Government. ACELG, University of Technology, Sydney.

28. National Commission of Audit. 2014. Towards Responsible Government: The Report of the National Commission of Audit. Australian Government, Canberra.

29. Organization for Economic Cooperation and Development (OECD). 2014. OECD Better Life Index, http://www.oecdbetterlifeindex.org/, accessed January 2015.

30. Pillora, S. and McKinlay, P. 2011. Evolution in Community Governance: Building on What Works, Volume 2, Literature Review. ACELG, University of Technology Sydney.

31. Poister, T.H., Pitts, D.W. and Edwards, L.H. 2010. Strategic management research in the public sector: A review, synthesis and future directions. The American Review of Public Administration, 40(5): 522-545.

32. Productivity Commission. 2014a. A Quick Guide to the Productivity Commission. Australian Government, Canberra, http://www.pc.gov.au/_data/assets/pdf_file/0005/64679/productivity-commissionquickguide-2014.pdf, accessed January 2015.

33. Productivity Commission. 2014b. Overcoming Indigenous Disadvantage: Key indicators 2014 , http://www.pc.gov.au/research/recurring/overcoming-indigenousdisadvantage/key-indicators-2014, accessed January 2015.

34. Productivity Commission. 2008. Assessing Local Government Revenue Raising Capacity: Research Report. Productivity Commission, Canberra.

35. Sansom, G., Dawkins, J. and Tan, S. 2012. The Australian model of metropolitan governance: Insights from Perth and South East Queensland. ACELG, University of Technology, Sydney.

36. Sansom, G. 2009. 'Commonwealth of Australia.' In: N. Steytler [Ed.] Local Government and Metropolitan Regions in Federal Systems: A global dialogue on federalism Volume 6. McGill-Queen's University Press, published for Forum of Federations, Montreal, pp 736.

37. Tan, S. and Artist, S. 2013. Strategic planning in Australian local government: A comparative analysis of state frameworks. ACELG, University of Technology, Sydney.

38. Van den Dool, L., van Hulst, M. and Schaap, L. 2010. More than a friendly visit: A new strategy for improving local governing capacity. Local Government Studies, 36(4): 551568.

39. Victorian Government. 2014. Local Government Planning and Reporting: Better Practice Guide (Draft). Department of Transport, Planning and Local Infrastructure, Melbourne.

40. Vogel, R. and Masal, D. 2014. Public leadership: A review of the literature and framework for future research. Public Management Review,

41. Wallis, J. and Dollery, B. 2002. Social capital and local government capacity. Australian Journal of Public Administration, 61(3): 76-85. 
Roberta Ryan, Ronald Woods

\section{Australijos vietos valdžios gebėjimai}

Anotacija

Straipsnyje analizuojama kiek efektyviai Australijos vietos valdžia, kaip svarbiausias subnacionalinio valdymo elementas, igyvendina savo funkcijas. Paslaugų teikimas ir vietos demokratija yra išskirtos kaip pagrindinès vietos valdžios funkcijos. Analizèje naudojamos viešojo administravimo, demokratijos ir vadybos, viešosios organizacijos, atskaitomybès ir gebèjimų paradigmos. „Gebẻjimų“ koncepcija apjungia daugumą problemų aptariamų šiame straipsnyje. Gebejjimų klausimai bet kuriuo atveju yra susiję su tuo, kiek vietos valdžia efektyviai igyvendina savo institucines funkcijas, kaip ji tai daro atsižvelgiant ị gero valdymo principus, ir kokios jos gebejimų dimensijos gali būtų reformuotos dèl poreikio atsiliepti i papildomus poreikius.

Roberta Ryan - Director UTS centre of Excellence for Local Government, University of Technology, Sydney

E-mail.: Roberta.Ryan@uts.edu.au

Ronald Woods - Lector UTS Centre of Excellence for Local Government, University of Technology, Sydney

E-mail.: Ronald.Woods@ uts.edu.au

Roberta Ryan - Sidnèjaus technologijos universiteto Vietos valdžios kompetencijos centro direktorè

E.paštas: Roberta.Ryan@uts.edu.au

Ronald Woods - Sidnèjaus technologijos universiteto Vietos valdžios kompetencijos centro lektorius

E.paštas: Ronald.Woods@ uts.edu.au

Straipsnis įteiktas redakcijai 2015 m. rugpjūčio mėn.; recenzuotas; parengtas spaudai 2015 m. rugsèjo mèn. 